\title{
Impaired Spatial Cognition and Synaptic Potentiation in a Murine Model of Human Immunodeficiency Virus Type 1 Encephalitis
}

\author{
Walter E. Zink, ${ }^{1,2}$ Eric Anderson, ${ }^{1,2}$ Jeffrey Boyle, ${ }^{1,2}$ Lynette Hock, ${ }^{3}$ Jorge Rodriguez-Sierra, ${ }^{1,2,4}$ \\ Huangui Xiong, ${ }^{1,2}$ Howard E. Gendelman, ${ }^{1,2,5}$ and Yuri Persidsky ${ }^{1,2}$ \\ ${ }^{1}$ Center for Neurovirology and Neurodegenerative Disorders, Departments of 2 Pathology and Microbiology, ${ }^{3}$ Preventative \\ and Societal Medicine, ${ }^{4}$ Cell Biology and Anatomy, and 5 Internal Medicine, University of Nebraska Medical Center, \\ Omaha, Nebraska 68198-5215
}

Injection of human immunodeficiency virus type 1 (HIV-1)infected human monocyte-derived macrophages (MDMs) into the basal ganglia of severe combined immunodeficient mice recapitulates histopathologic features of HIV-1 encephalitis (HIVE). Here, we show that the neural damage in HIVE mice extends beyond the basal ganglia and is associated with cognitive impairment. Morris water maze tests showed impaired spatial learning $8 \mathrm{~d}$ after MDM injection. Moreover, impaired synaptic potentiation in the hippocampal CA1 subregion was demonstrated at 8 and $15 \mathrm{~d}$. By day 15, post-tetanic, shortterm, and long-term potentiation were reduced by 14.1, 29.5, and $45.3 \%$ in HIVE mice compared with sham-injected or control animals. Neurofilament (NF) and synaptophysin (SP) antigens were decreased significantly in the CA2 hippocampal subregion of HIVE mice with limited neuronal apoptosis. By day 15, the CA2 region of HIVE mice expressed 3.8- and 2.6-fold less NF and SP than shams. These findings support the notion that HIV-1-infected and immune-competent brain macrophages can cause neuronal damage at distant anatomic sites. Importantly, the findings demonstrate the value of the model in exploring the physiological basis and therapeutic potential for HIV-1-associated dementia.

Key words: monocyte-derived macrophages; HIV-1associated dementia; HIV-1 encephalitis; HIVE mice; spatial cognition; Morris water maze; synaptic potentiation; neurofilament; synaptophysin
Cognitive, motor, and behavioral deficits occur late in the course of most lentiviral infections. For the human immunodeficiency virus type 1 (HIV-1) (Michaels et al., 1988; Price et al., 1988), the simian immunodeficiency virus (Chakrabarti et al., 1991; Hurtrel et al., 1993), and the ungulate lentiviruses (Gendelman et al., 1985; Narayan and Clements, 1989; Clements et al., 1994; Narayan et al., 1995), neurologic impairments occur with progressive viral infection and infiltration of peripheral monocytes into brain perivascular spaces and parenchyma. In the case of HIV-1, infected individuals commonly experience apathy, withdrawal, and frank disorientation to time and place. Before the widespread implementation of highly active anti-retroviral therapy (HAART), 17-33\% of infected adults and 50\% of infected children exhibited cognitive, behavioral, and motor impairments (Janssen et al., 1991; Maschke et al., 2000). Despite the diminished incidence of HIV-1-associated dementia (HAD), now at $7 \%$, since the implementation of HAART (Dore et al., 1999), the greater life expectancy may increase disease prevalence.

Histologic features observed in HIV-1 encephalitis (HIVE) include macrophage infiltration of basal ganglia and subcortical white matter, diffuse microglial activation, reactive astrocytosis, myelin pallor, and neuronal injury and loss. Collectively, these histopathologic features have been reproduced in a small animal model system of disease. Injection of human monocyte-derived

\footnotetext{
Received July 24, 2001; revised Nov. 2, 2001; accepted Nov. 27, 2001.

We extend special thanks to Robin Taylor and Clancy Williams for outstanding administrative and computer support and to Casey Diekmann for excellent technical support.

Correspondence should be addressed to Dr. Howard E. Gendelman, Center for Neurovirology and Neurodegenerative Disorders, University of Nebraska Medical Center, Omaha, NE 68198-5215. E-mail: hegendel@unmc.edu.

Copyright (C) 2002 Society for Neuroscience $\quad 0270-6474 / 02 / 222096-10 \$ 15.00 / 0$
}

macrophages (MDMs) into the caudate and putamen of severe combined immunodeficient (SCID) mice produces local histopathologic alterations that mimic salient features of HIVE in humans (Persidsky et al., 1996, 1997). Although this model has proven useful for studying viral spread among human macrophages in brain and inflammation, it previously was unknown whether quantifiable cognitive impairment and diff use physiological and pathological alterations could occur. It has previously been shown that the SCID phenotype is not associated with spatial cognition deficits (Petitto et al., 1999) and that both murine neural and human MDM antigens can be detected distinctly in HIVE mice (Persidsky et al., 1995).

In the present study, mice were examined in the Morris water maze (MWM) (Morris, 1984) at 4, 8, and $15 \mathrm{~d}$ after injection with HIV-1-infected and uninfected MDM, vehicle (sham), and unmanipulated controls. At each of the time points, hippocampal slices were excised, and synaptic potentiation was measured within the CA1 subregion. Neuronal apoptosis, dendritic arbor, and synaptic density within the hippocampus were quantified using the terminal deoxynucleotidyl transferase-mediated biotinylated UTP nick end labeling (TUNEL) assay, a monoclonal antibody for the neuronal cytoskeletal antigen neurofilament (NF), and a monoclonal antibody for the presynaptic synaptophysin (SP). To the best of our knowledge, these experiments are the first to demonstrate clear relationships between cognitive impairment, synaptic physiology, and neuronal morphology in HIVE animals, supporting the value of the model for studies of disease pathogenesis and therapeutic development for HAD.

\section{MATERIALS AND METHODS}

Isolation and culture of primary human monocytes. Monocytes were obtained from leukopheresis of HIV-1 and hepatitis B seronegative 
donors and purified by counter current centrifugal elutriation (Gendelman et al., 1988). Wright-stained cytospins prepared from cell suspensions were immunolabeled with CD68 (clone KP-1, M0814; Dako, Carpinteria, CA) and shown to be $>98 \%$ pure. Monocytes were suspended in Teflon flasks $\left(2 \times 10^{6}\right.$ cells $\left./ \mathrm{ml}\right)$ in DMEM (Sigma, St. Louis, MO) with $10 \%$ heat-inactivated pooled human serum, $1 \%$ glutamine, 50 $\mu \mathrm{g} / \mathrm{ml}$ gentamicin (Sigma), $10 \mu \mathrm{g} / \mathrm{ml}$ ciprofloxacin (Sigma), and 1000 $\mathrm{U} / \mathrm{ml}$ highly purified recombinant human macrophage colony stimulating factor (MCSF) (a generous gift from Genetics Institute, Inc., Cambridge, MA). Monocytes were cultured with MCSF $7 \mathrm{~d}$ after elutriation (to allow differentiation to MDM). Culture medium was changed every 2-3 d. All tissue culture reagents were screened before use and found negative for endotoxin $(<10 \mathrm{pg} / \mathrm{ml})$ (Associates of Cape Cod., Inc., Woods Hole, MA) and mycoplasma contamination (Gen-probe II; Genprobe Inc., San Diego, CA).

HIV-1 infection of MDMs. After $7 \mathrm{~d}$ in Teflon flask suspension culture, MDMs were infected with the macrophage-tropic strain HIV-1 $1_{\mathrm{ADA}}$ (Gendelman et al., 1988) at multiplicity of infection of 0.01 infectious virus per target cell. Reverse transcriptase (RT) activity was determined in triplicate samples of culture fluids added to a reaction mixture of $0.05 \%$ Nonidet P-40 (Sigma), $10 \mu \mathrm{g} / \mathrm{ml}$ poly(A), $0.25 \mu \mathrm{g} / \mathrm{ml}$ oligo(dt) (Amersham Biosciences, Piscataway, NJ), $5 \mathrm{~mm}$ dithiothreitol (Amersham Biosciences), $150 \mathrm{~mm} \mathrm{KCl}, 15 \mathrm{~mm} \mathrm{MgCl}_{2}$, and $\left[{ }^{3} \mathrm{H}\right]$ dideoxythymidine 5'-triphosphate $(2 \mathrm{Ci} / \mathrm{mmol}$; Amersham Biosciences, Arlington Heights, IL) in $\mathrm{pH} 7.9$ Tris- $\mathrm{HCl}$ buffer for $24 \mathrm{hr}$ at $37^{\circ} \mathrm{C}$. Radiolabeled nucleotides were precipitated with cold $10 \%$ trichloroacetic acid and $95 \%$ ethanol in an automatic cell harvester (Skatron Inc., Sterling, VA) on paper filters. Radioactivity was estimated by liquid scintillation spectroscopy (Kalter et al., 1991).

Ten to twenty percent of HIV-1-infected MDMs expressed p24 viral antigens as determined by immunocytochemistry (Dako; M0857, 1:10 dilution). Cytospin preparations of HIV-1-infected cells were fixed in ice-cold absolute acetone/methanol (1:1) for $10 \mathrm{~min}$ at $-20^{\circ} \mathrm{C}$. Antibodies to HIV-1 p24 were applied for $60 \mathrm{~min}$, followed by a biotinylated anti-mouse $\mathrm{IgG}_{2}$, avidin-biotin complex, and 3,3'-diaminobenzidine peroxidase substrate. Viral antigen-positive cells were counted in a Nikon Microphot-FXA microscope using a $20 \times$ objective in 10 random fields. All experiments were performed in triplicate.

HIVE SCID mice. Forty-eight SCID mice (male C.B.-17/IcrCrlscidBR, 3-4 weeks old) were purchased from Charles River Laboratories (Wilmington, MA). Animals were maintained in sterile microisolator cages under pathogen-free conditions in the Laboratory of Animal Medicine at the University of Nebraska Medical Center in accordance with ethical guidelines for care of laboratory animals set forth by the National Institutes of Health. Mice were acclimated to a $12 \mathrm{hr}$ light/dark cycle. Food and water were available ad libitum. All mice were ear tagged for individual identification. Intracerebral inoculations of $\mathrm{HIV}-1_{\mathrm{ADA}^{-}}$ infected MDMs were performed after intraperitoneal anesthesia (100 $\mathrm{mg} / \mathrm{kg}$ ketamine and $16 \mathrm{mg} / \mathrm{kg}$ xylazine). At the day of brain injection (5 d after infection), MDMs were pelleted and then resuspended at $2 \times 10^{7}$ cells $/ \mathrm{ml}$ in serum-free DMEM. Anesthetized mice were placed in a stereotactic apparatus (Stoetling Co., Wood Dale, IL) designed for mice. The animal's head was secured with ear bars and mouthpiece during the injection (Cunningham and McKay, 1993). A $1 \mathrm{ml}$ tuberculin syringe (Becton Dickinson, Franklin Lakes, NJ) with a 26 gauge needle was used. Each animal in the HIV-1 MDM and MDM treatment groups received $10 \mu \mathrm{l}$ of suspension containing $3.0 \times 10^{5} \mathrm{HIV}$-1-infected or uninfected cells, inoculated into the left hemisphere (targeting caudate and/or putamen, with coordinates (Persidsky et al., 1996). Sham-operated animals received $10 \mu \mathrm{l}$ of serum-free DMEM.

Morris water maze. Mice were introduced into the perimeter of a circular water-filled tank $91 \mathrm{~cm}$ in diameter and $110 \mathrm{~cm}$ in height, with a video camera (Burle Securities, Lancaster, PA) suspended $170 \mathrm{~cm}$ above the liquid surface. Tracking software (PolyTrack, San Diego Instruments) recorded the path of the rodent by light/dark contrast detection for subsequent analysis. At four compass point (N, S, E, W), extra-maze visual cues were depicted in white on the black interior wall of the tank. A square "escape platform" $(13 \mathrm{~cm} \times 13 \mathrm{~cm})$ was placed $2 \mathrm{~cm}$ below water level in one of the quadrants. The detection system was programmed to terminate the trial when the animal reached the escape platform. For the purpose of longitudinal testing, the escape platform was moved to a different quadrant at each time point. Water temperature was maintained at $15-17^{\circ} \mathrm{C}$.

One day after delivery from Charles River Laboratories, each animal was acclimated to the MWM in the absence of escape platform for 90 sec. Within 1 week after acclimation, mice were injected. At 3, 7, and $15 \mathrm{~d}$ after injection, each animal was introduced into the MWM for up to 90 sec per trial in the presence of a hidden escape platform. The release positions around the perimeter of the maze were different for each trial, and the order was determined pseudorandomly. Trials were terminated when the mouse reached the escape platform or after $90 \mathrm{sec}$. After termination, the mouse remained on the escape platform for $10 \mathrm{sec}$, was removed from the apparatus, dried, given food and water, and allowed to rest for at least $10 \mathrm{~min}$ or until core body temperature returned to $35-37^{\circ}$ C. Motor and motivational performance were evaluated at each time point by recording the swim speed during the initial trial of each day. Two days after injection, one mouse in the MDM group experienced right hemiparesis, likely reflecting partial transection of the left internal capsule. During injection into basal ganglia, the internal capsule is transected in $<1: 300$ injections. This mouse was eliminated from analysis, leaving final sample sizes of the MDM, HIV-1 MDM, sham, and unmanipulated groups at $11,12,12$, and 12 mice, respectively.

Within each time point, the escape latency of each mouse was measured in 9-10 trials. Two-way ANOVA was used to test for differences between groups, between trials, and group $\times$ trial interactions. If the overall tests for main effect were significant, pairwise comparisons were conducted to assess differences. Tukey's adjustment for multiple pairwise comparisons was used to maintain the level of significance. Separate ANOVAs were performed for days 4,8 , and 15 . Within each group, a main effect of trial, such that the escape latency at trial 10 was less than that at trial 1, was used as a criterion for intact learning. All tests were one-way, two-sided, and had $\leq 0.05$ significance.

Preparation of hippocampal slices and recordings of evoked field potentials. Transverse mouse brain slices were prepared as described in rats (Xiong et al., 1996). Mice were transported in microisolator cages to the electrophysiology recording stations housed within biosafety level 3 infection containment. Mice were anesthetized with metofane and decapitated, and brains were removed. Hippocampi ipsilateral to the injection site were separated and immediately placed in an ice-cold $\left(4^{\circ} \mathrm{C}\right)$ oxygenated artificial CSF (ACSF) containing (in $\mathrm{mM}$ ): $124 \mathrm{NaCl}, 3 \mathrm{KCl}$, $2 \mathrm{CaCl}_{2}, 2 \mathrm{MgCl}_{2}, 1 \mathrm{NaH}_{2} \mathrm{PO}_{3}, 26 \mathrm{NaCO}_{3}$, and 10 glucose. ACSF was equilibrated with $95 \% \mathrm{O}_{2}$ and $5 \% \mathrm{CO}_{2}$; the resulting $\mathrm{pH}$ was 7.32-7.46. Transverse hippocampal slices (400 $\mu \mathrm{m}$ thick) were cut and kept in a humidified/oxygenated holding chamber at room temperature for $1 \mathrm{hr}$ before being transferred to the recording chamber where they were submerged in a continuously perfused, oxygenated, $30^{\circ} \mathrm{C}$ ACSF solution at a constant flow rate of $2 \mathrm{ml} / \mathrm{min}$.

Orthodromic constant current stimuli $(0.05 \mathrm{~Hz})$ were delivered through a bipolar tungsten electrode (insulated except for the tip) placed in the Schaffer collateral pathway to CA3. The intensity $(50-400 \mu \mathrm{A})$ and duration $(0.01-0.05 \mathrm{msec})$ of stimulation were adjusted to generate $\sim 30-40 \%$ of a maximal response. EPSPs were recorded in the stratum radiatum within the CA1 hippocampal subregion with an Axopath-1D amplifier (Axon Instruments, Foster City, CA) interfaced with a Dell Pentium II PC computer (Dell, Round Rock, TX), acquired digitized (at a frequency of $2.5 \mathrm{kHz}$ ), and analyzed using pCLAMP software (Axon Instruments). The initial slopes of field EPSPs were calculated in units of percentage of control. Separate phases of synaptic potentiation were defined as post-tetanic potentiation (PTP) $(0-5 \mathrm{~min})$, short-term potentiation (STP) (10-14 min), and long-term potentiation (LTP) (56-60 min) and compared using a one-way, two-sided ANOVA analysis at a 0.05 level of significance. The rostral-most portion of each hippocampal subregion was $\geq 500 \mu \mathrm{m}$ from the injection site. After stimulation parameters were achieved, a 30 min control ensured that a working synapse was analyzed before high-frequency stimulation (HFS).

TUNEL. TUNEL was performed on paraffin sections using the in situ cell death detection kit (Roche Diagnostics, Chicago, IL). Briefly, dewaxed sections were permeabilized with proteinase $\mathrm{K}(10 \mu \mathrm{g} / \mathrm{ml}$ in Tris- $\mathrm{HCl}, 15 \mathrm{~min}$ at $37^{\circ} \mathrm{C}$ ) and incubated with the TUNEL reaction mixture $\left(60 \mathrm{~min}\right.$ at $\left.37^{\circ} \mathrm{C}\right)$. Sections were viewed using a Nikon Eclipse (E800) microscope.

Immunohistochemistry. Whole mouse brains were collected at necropsy. Tissue was fixed in $4 \%$ paraformaldehyde for $48 \mathrm{hr}$. Neuronal arbor was detected with mouse mAb against NF (Dako; M0762, 1:50 dilution). Synaptic density was detected with mouse mAb against SP (Chemicon, Temecula, CA; 329, 1:50 dilution). The xenograft was detected with mouse $\mathrm{mAb}$ against a human vimentin (Roche Diagnostics; 1112 457, 1:50 dilution), as described (Persidsky et al., 1996). Images were gathered using a MagnaFire digital camera and software (Optronics, Goleta, CA). Total area occupied by peroxidase positivity was quan- 

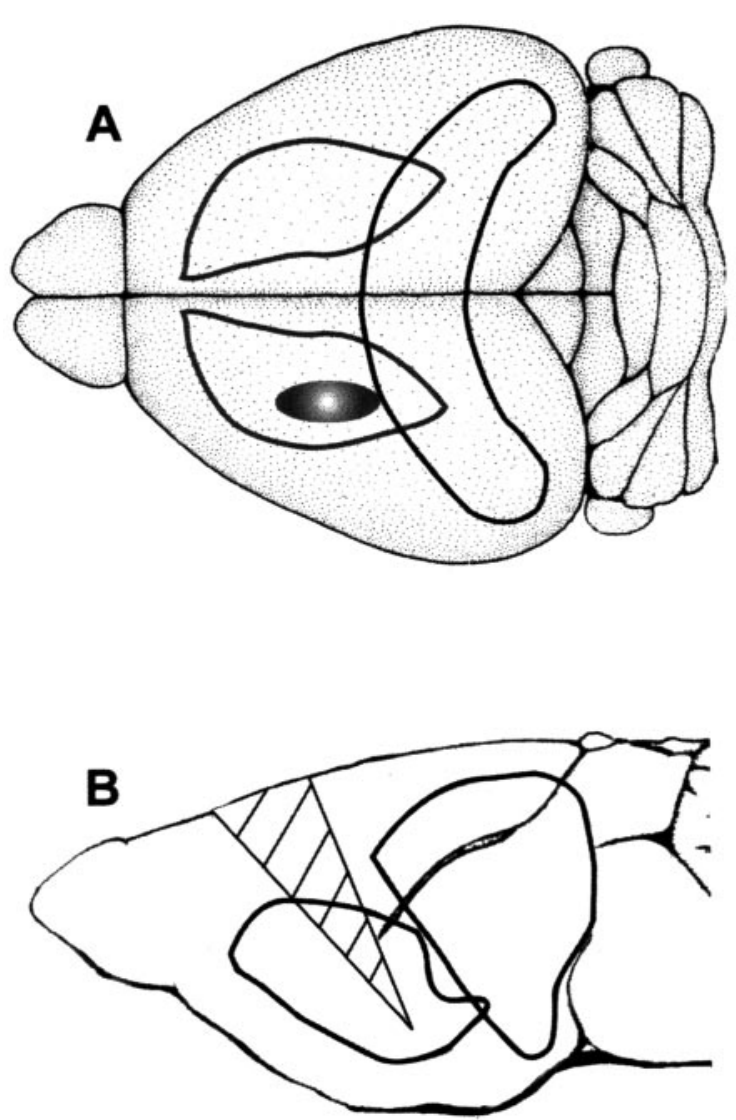

Figure 1. Location of xenograft and needle tract in the brains of SCID mice. $A$ shows a schematic representation of the position of human MDMs injected into the left basal ganglia of SCID mice. The ellipse represents the sum area occupied by human MDMs. The hippocampal formation is also shown. The triangle in $B$ shows the sum of needle tracts for all mice injected with HIV-1-infected or uninfected MDMs or vehicle control. The fissure represents the lateral ventricle.

tified using Image-Pro Plus software (Media Cybernetics, Silver Spring, $\mathrm{MD)}$.

\section{RESULTS}

Reproducible xenograft placement in the left basal ganglia was done by sterotactic injections. Among the 36 mice analyzed, the majority $(>90 \%)$ of injected cells found in brain parenchyma were located in the gray field (Fig. 1A), and no mice displayed human cells in the hippocampal formation by immunohistochemical tests. Variations in the angle of needle entry are shown in Figure $1 B$.

\section{Morris water maze testing}

Cognition was examined in SCID mice after infection of HIV1-infected MDM, MDM, and vehicle control (sham). The criterion for demonstrable spatial cognition was a group mean escape latency at trial 10 less than that at trial 1 (Fig. 2). A frank inability to learn was manifest by a final mean escape latency statistically indistinguishable from initial latency (Fig. $2 B, H I V-1$ and $M D M$ mice). The performance of unmanipulated animals (data not shown) was statistically indistinguishable from sham-operated mice at all time points. At day 4, two-way ANOVA revealed no effect of group and no significant group $\times$ trial interactions. Within each group, an effect of trial was observed $(p<0.0001)$, suggesting progressive recognition of spatial cues. By day 8 , mice in the HIV-1 MDM and MDM groups developed cognitive impairment, as evidenced by failure to acquire spatial information (Fig. $2 B$ ). Two-way ANOVA of all groups at day 8 showed a significant effect of group $(p<0.01)$ and trial $(p<0.05)$. No group $\times$ trial interactions were resolved. Within the HIV-1 MDM and MDM groups, ANOVA showed no effect of trial at day 8 , demonstrating failed acquisition of spatial information. No difference between HIV-1 MDM and MDM groups was detected at any time point.

MWM testing at day 15 showed no effect of group, no group $\times$ trial interactions, and a significant effect of trial $(p<0.0001)$. The hidden escape platform was moved to a different quadrant each day to reduce the contaminating effects of longitudinal testing. Despite this approach, MWM testing conducted at successive time points shows a progressive decrease in the initial mean escape latencies (Fig. $2 A-C$, trial 1 ), likely reflecting some measure of longitudinal task familiarization.

The basal ganglia are known to modulate fine motor function in mammals, and an inflammatory lesion in these structures could cause slowed swim speed, leading to reduced escape latency in the presence of intact cognition. To determine whether the increased MWM escape latencies shown in Figure $2 B$ reflect cognitive or motor impairment, we analyzed mouse swim speeds at trial 1 of each time point. At all time points, HIV-1 MDM and MDM mice demonstrated swim speeds indistinguishable from or greater than shams, indicating that xenograft injection into basal ganglia did not cause motor defects. In fact, on day $8, \mathrm{HIV}-1$ MDM mice showed significantly increased initial swim speeds compared with sham and MDM animals $(* p<0.05)$. On day 15 , both HIV-1 MDM and MDM mice showed significantly elevated swim speeds when compared with shams $(* p<0.05)$.

\section{Electrophysiology}

We investigated whether MWM performance could be associated with altered synaptic physiology. We killed animals at equivalent time points after injection, dissected and sectioned the hippocampal formation ipsilateral to the injection, and recorded EPSPs within the CA1 region. Because of the length of time required to gather electrophysiologic recordings, mice were analyzed by electrophysiology tests at days 3, 4, and 5 (early), at days 7, 8, and 9 (intermediate), and at days 14, 15, and 16 (late). At each time point, one to three slices from three to six animals were tested. Electrophysiology recordings taken at days 3, 4, and 5 after MDM injection were combined to yield " $3-5$ days" data as shown in Figure $4 A$. Data were combined similarly at the intermediate and late time points as shown in Figure $4, B$ and $C$. Each data set includes mice from three separate litters.

Figure 4 shows electrophysiological traces generated from HIV-1 MDM, MDM, and sham-injected SCID mice at 4, 8, and $15 \mathrm{~d}$ after injection. Error bars represent the SEM among slices. A 30 min control recording was conducted in each slice. Results from slices with large fluctuation (more than \pm 2 SD) in basal activity were rejected. At the end of the initial 30 min control period, HFS $(100 \mathrm{~Hz}, 0.5 \mathrm{sec})$ was delivered twice at $20 \mathrm{sec}$ intervals. At all time points, sham animals displayed HFSdependent synaptic enhancement as depicted in Figure $4 A-C$ (black traces). At 6-8 and 14-16 d after injection, HIV-1 MDM and MDM mice showed reduced synaptic enhancement compared with shams (see Fig. $4 B, C$ ). The reduced enhancement was more pronounced in the HIV-1 MDM than in the MDM mice.

Synaptic enhancement after HFS is divided into three phases (Bliss and Collingridge, 1993). PTP is the phase immediately after HFS. For most slices, the period of PTP includes or pre- 


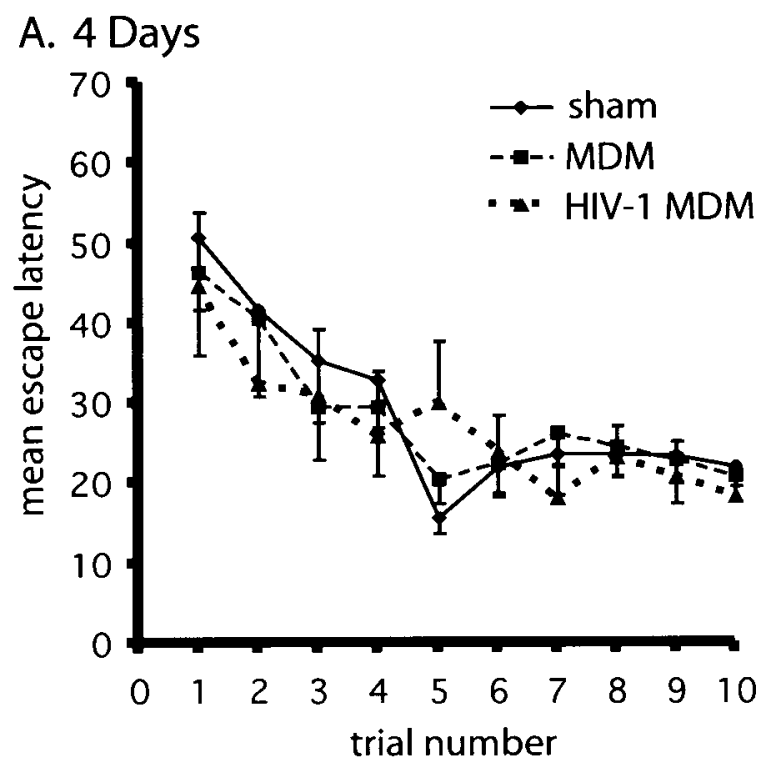

\section{B. 8 Days}
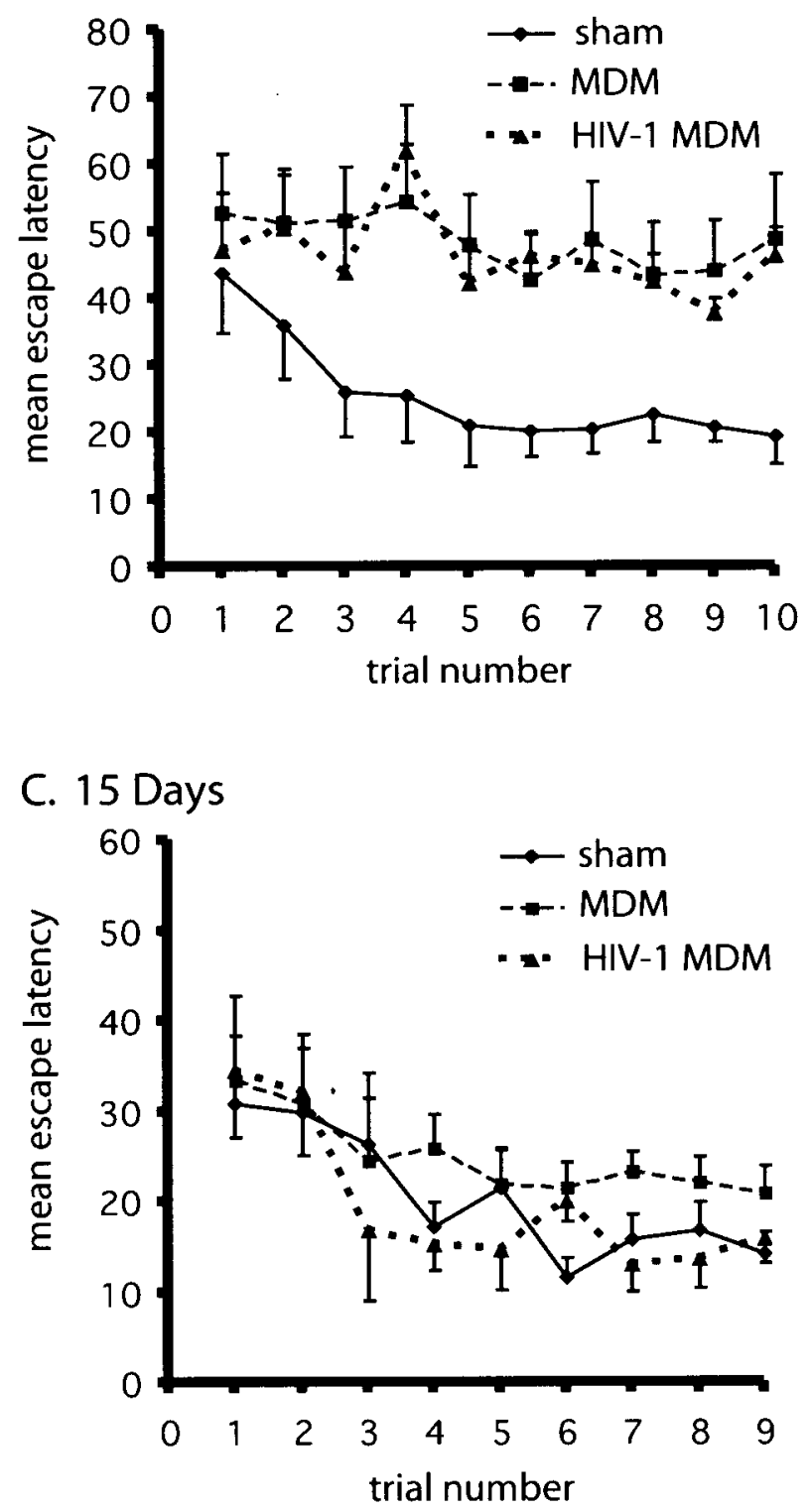

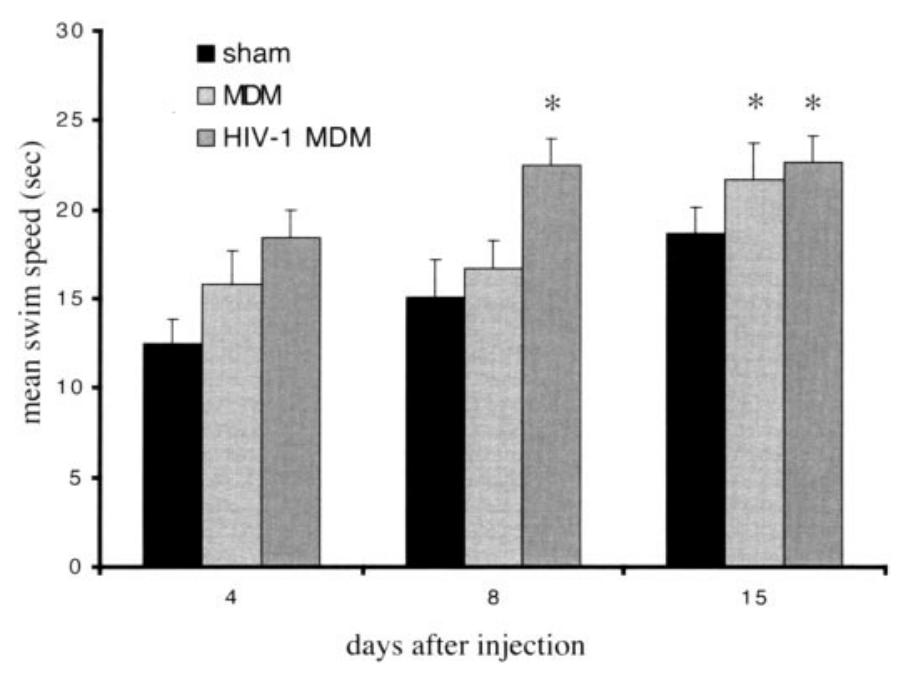

Figure 3. Mouse swim speeds at 4, 8, and $15 \mathrm{~d}$ after injection. The bar graphs represent mean swim speeds during the first Morris water maze trial at each time point. Analysis of day 8, trial 1 (middle 3 bars) revealed a significant effect of group. HIV-1 MDM-injected mice displayed a faster mean swim speed than MDM-injected and shams. Analysis of day 15, trial 1 swim speeds (rightmost 3 bars) also revealed a significant effect of group $\left({ }^{*} p<0.05 ;\right.$ ANOVA, Tukey-Kramer $)$

cedes the maximum HFS-dependent response and manifests graphically as the phase of the curve with a steep positive slope. In C.B-17/IcrCrl-SCID mice, the initial EPSP slope increased by 140-350\% over baseline (control) for the initial 1-5 min after HFS. In experimental mice analyzed from days 3-5, no significant effect of group was observed (ANOVA; $p>0.05$ ). Quantification of PTP 7-9 d after treatment showed significantly decreased PTP in mice injected with HIV-1 MDM (ANOVA, Tukey-Kramer; $\left.{ }^{* *} p<0.001\right): 214 \pm 25 \%$ (sham), $226 \pm 27 \%$ (MDM), and $112 \pm$ 5\% (HIV-1 MDM). At days 14-16, both HIV-1 MDM and MDM mice showed significant reductions compared with shams (ANOVA and Tukey-Kramer; ${ }^{*} p<0.01, * *<0.001$ ): $196 \pm$ $11 \%$ (sham), $162 \pm 6 \%$ (MDM), and $110 \pm 6 \%$ (HIV-1 MDM).

STP is the phase of gradual decay in potentiated EPSPs. At days 3-5, STP was statistically indistinguishable among the treatment groups (ANOVA; $p>0.05$ ). By later time points, however, STP showed susceptibility to the xenografts. At days 7-9, slices from sham and MDM animals showed indistinguishable mean STP values of $224 \pm 20$ and $200 \pm 11$, respectively, whereas HIV-1 MDM animals showed a significantly decreased mean STP value of $127 \pm 4$ (ANOVA and Tukey-Kramer; ${ }^{*} p<0.01$ ). By days 14-16, all three groups were statistically resolved (ANOVA and Tukey-Kramer; $\left.{ }^{*} p<0.01,{ }^{*} p<0.001\right): 196 \pm 15$ (sham) $>$ $156 \pm 7(\mathrm{MDM})>99 \pm 7(\mathrm{HIV}-1 \mathrm{MDM})$.

LTP can appear graphically as an asymptote persisting hours to days above the baseline level of responsiveness. In this study, we terminated LTP recordings $90 \mathrm{~min}$ after HFS. The 3-5 and 7-9 time point analyses showed no effect of group on LTP (ANOVA; $p>0.05$ ). Analysis at days 14-16 (see Fig. 5C, right bars) showed decreased LTP in mice injected with HIV-1 MDM (ANOVA and

$\leftarrow$

Figure 2. Learning in the Morris water maze. Murine cognition was analyzed at 4, 8, and $15 \mathrm{~d}$ after injection. The MDM group contained 11 mice and other groups contained 12. Each data point represents mean \pm SEM. Two-way ANOVA applied at each time point revealed a significant effect of trial at each time point. 

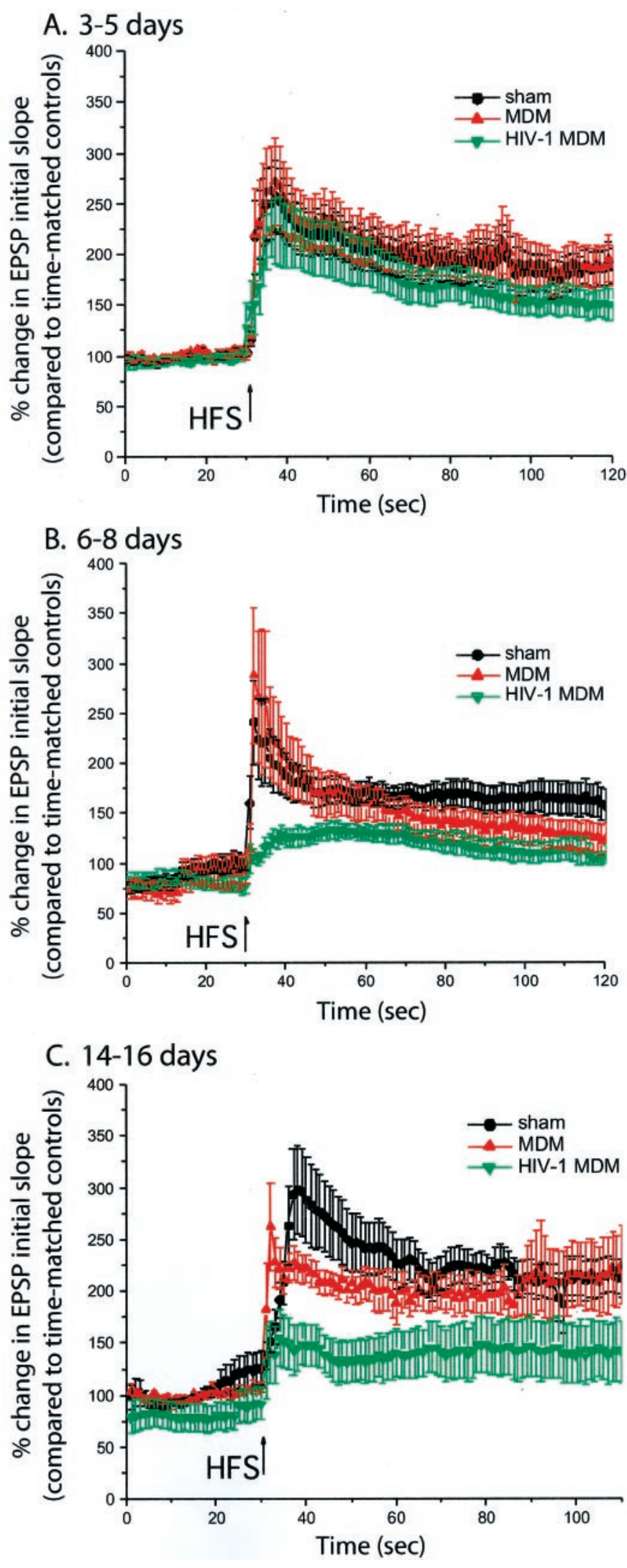

Figure 4. Synaptic potentiation recorded in the CA1 hippocampal subregion at 3-5 $\mathrm{d}(A), 6-8 \mathrm{~d}(B)$, and $14-16 \mathrm{~d}(C)$ after MDM injection. Hippocampi from mice injected with media alone (sham), uninfected human monocyte-derived macrophages (MDM), and HIV-1-infected human monocyte-derived macrophages $(H I V-1 M D M)$ were analyzed. Each
Tukey-Kramer; ${ }^{* *} p<0.001$ ): $212 \pm 7 \%$ (sham), $160 \pm 16 \%$ (MDM), and $116 \pm 4 \%$ (HIV-1 MDM).

\section{Histopathology}

Next we determined whether transient changes in mouse cognition and progressive changes in synaptic physiology were associated with morphologic changes in the hippocampus. At days 4, 8, and 15, we immunostained coronal hippocampal sections from four HIV-1 MDM and four MDM-injected mice with mAb against human vimentin and found that 0 of 24 mice contained human cells. TUNEL staining was performed on four animals in each treatment groups at days 4, 8, and 15 (36 total). Only one of four mice in the HIV-1 MDM and MDM groups showed TUNEL-positive nuclei in hippocampus at day 4. At days 8 and 15, no mice showed evidence of hippocampal apoptosis.

Histochemical analysis of neuronal antigen distribution was accomplished using mAbs against mouse NF, a cytoskeletal protein localized primarily in neuronal processes, and SP, a transmembrane protein localized in active synapses. NF-stained cells were visualized in the $\mathrm{CA} 2$ regions ipsilateral and contralateral to the injection as shown in Figure 6. We then selected a region within CA2 that expressed dense NF networks for quantification and is illustrated in Figure 7. Quantification of NF and SP staining within CA2 was accomplished using ImagePro Plus software and is shown in Figures 8 and 9. Four days after injection, HIV-1 MDM-injected mice displayed a $76 \%$ reduction in NF expression and MDM-injected mice displayed a $73 \%$ reduction in NF compared with shams. Eight days after injection, HIV-1 MDM mice showed an $80 \%$ reduction and MDM mice showed a $64 \%$ reduction in NF compared with shams. Fifteen days after injection, HIV-1 MDM mice showed a 73\% reduction and MDM mice showed a $53 \%$ reduction in NF compared with shams. All xenograft-dependent reductions in NF expression were statistically significant compared with shams (ANOVA and TukeyKramer; $* p<0.05,{ }^{*} p<0.01$ ).

SP density was next evaluated using the same approach developed for NF. Four days after injection, HIV-1 MDM-injected mice displayed a $58 \%$ reduction in SP expression and MDMinjected mice displayed a $56 \%$ reduction in SP compared with shams. Eight days after injection, HIV-1 MDM mice showed a $55 \%$ reduction and MDM mice showed a $44 \%$ reduction in SP compared with shams. Fifteen days after injection, HIV-1 MDM mice showed a $61 \%$ reduction and MDM mice showed a $54 \%$ reduction in SP compared with shams. All xenograft-dependent reductions in SP expression were statistically significant compared with shams (ANOVA and Tukey-Kramer; ${ }^{*} p<0.05$ ).

\section{DISCUSSION}

In this report, a SCID mouse model for HIVE (Persidsky et al., 1996; Persidsky and Gendelman, 1997) was used to explore the

\footnotetext{
$\leftarrow$

group includes 6-10 sections analyzed independently. Slices were dissected immediately after animals were killed, bathed in ACSF, and analyzed within $4 \mathrm{hr}$. A stimulating electrode applied current to the Shaffer collateral pathway. A recording electrode measured field potential in the CA1 region. Each point represents the initial slope of the falling phase of the evoked EPSPs recorded from the CA1 dendrite field before and after high frequency stimulation $(H F S)(100 \mathrm{~Hz}, 0.5 \mathrm{sec})$. No slices showed signs of needle trauma under magnification $(40 \times)$. Data points represent mean \pm SEM. No significant between-group differences were observed in synaptic potentiation within the CA2 subregion 3-5 d after injection $(A)$. Significant differences in synaptic potentiation were observed after HFS at days 6-8 $(B)$ and 14-16 $(C)$. Recordings were terminated $80-90$ min after HFS.
} 
relationship between cognitive function, physiology, and neuropathology after injection of human MDM into the basal ganglia. HIVE mice displayed deficient spatial cognition at day 8 but by day 15, cognition of HIVE animals returned to baseline (Fig. 2). HIVE SCID mice did not suffer motor deficits but in fact swam significantly faster than controls at all time points, possibly reflecting increased anxiety (Fig. 3).

We chose to measure HFS-dependent synaptic enhancement in the CA1 hippocampal subregion on the basis of previous studies correlating impaired enhancement in the murine hippocampus with spatial learning deficits in transgenic mice (McHugh et al., 1996; Molinari et al., 1996; Lu et al., 1997; Nalbantoglu et al., 1997; Chapman et al., 1999). To the best of our knowledge, these experiments are the first to demonstrate hippocampal synaptic enhancement in SCID mice. HIVE SCID mice showed a progressive decrease in synaptic function (Figs. 4, 5) in parallel with decreased cognition at day 8 . By day 15, multiple phases of synaptic potentiation were impaired in both xenograft groups, whereas MWM performance revealed indistinguishable cognition among treatment groups. These ostensibly incongruent findings at the late time point may be explained by the plasticity of the juvenile brain. Mice were injected between 3 and 5 weeks of age, before calcification of the skull and fusion of the cranial sutures, at an age when undamaged brain regions may be recruited into processes of learning and memory after damage to hippocampus, limbic system, or cortex. The increased ability of juvenile humans and animals to compensate for injury-dependent neurologic deficits is well documented and has been reviewed recently (Stiles, 2000). In general, it is not uncommon for changes in hippocampal synaptic plasticity to occur in temporal discordance with changes detected by the MWM (Ho et al., 2000; Murphy et al., 2000; Uetani et al., 2000; Kubota et al., 2001).

Hippocampal apoptosis was rare in HIVE mice. Although hippocampal neurons remained viable, a visible and quantifiable reduction in NF and SP immunoreactivity after xenograft injection was detected (Figs. 6, 7, 8, 9). Importantly, decreased NF and SP staining was detected distant from injected cells, suggesting a diff use mechanism underlying MDM-dependent neuronal injury. It is possible that xenograft implantation causes generalized disruption of amino acid uptake into brain as observed in models of CNS ischemia (Rosenstein and Silverman, 2000). Alternatively, antigen distribution in the mammalian hippocampus may change during acute injury, as has been shown to occur in the mammalian brain during aging (Van der Zee et al., 1997). Finally, xenograft implantation may lead to covalent modification of intermediate filaments (e.g., NF) and presynaptic bouton structural components (e.g., SP) in HIVE mice such that antibodies react differently in paraffin sections. Inflammation-dependent covalent modification of NF is particularly likely because covalent modification of intermediate filaments has been implicated in animal models of toxin-mediated neuronal neurodegeneration (Heijink et al., 2000; Sills et al., 2000), amyotrophic lateral sclerosis (Chou et al., 1998), and Lewy body dementia (Montine et al., 1995). In any of these scenarios, findings shown here and the previous finding of decreased dendritic arbor in the ipsilateral and contralateral cortex 4 weeks after HIV-1 MDM injection (Persidsky et al., 1997) support the idea that MDM can cause altered neuronal morphology at distant anatomic sites.

Together, these data support three major conclusions. First, impaired cognition, the distinguishing clinical feature of HAD, now has been demonstrated in the HIVE SCID mouse model after a single injection, adding relevance to its utility for mecha-
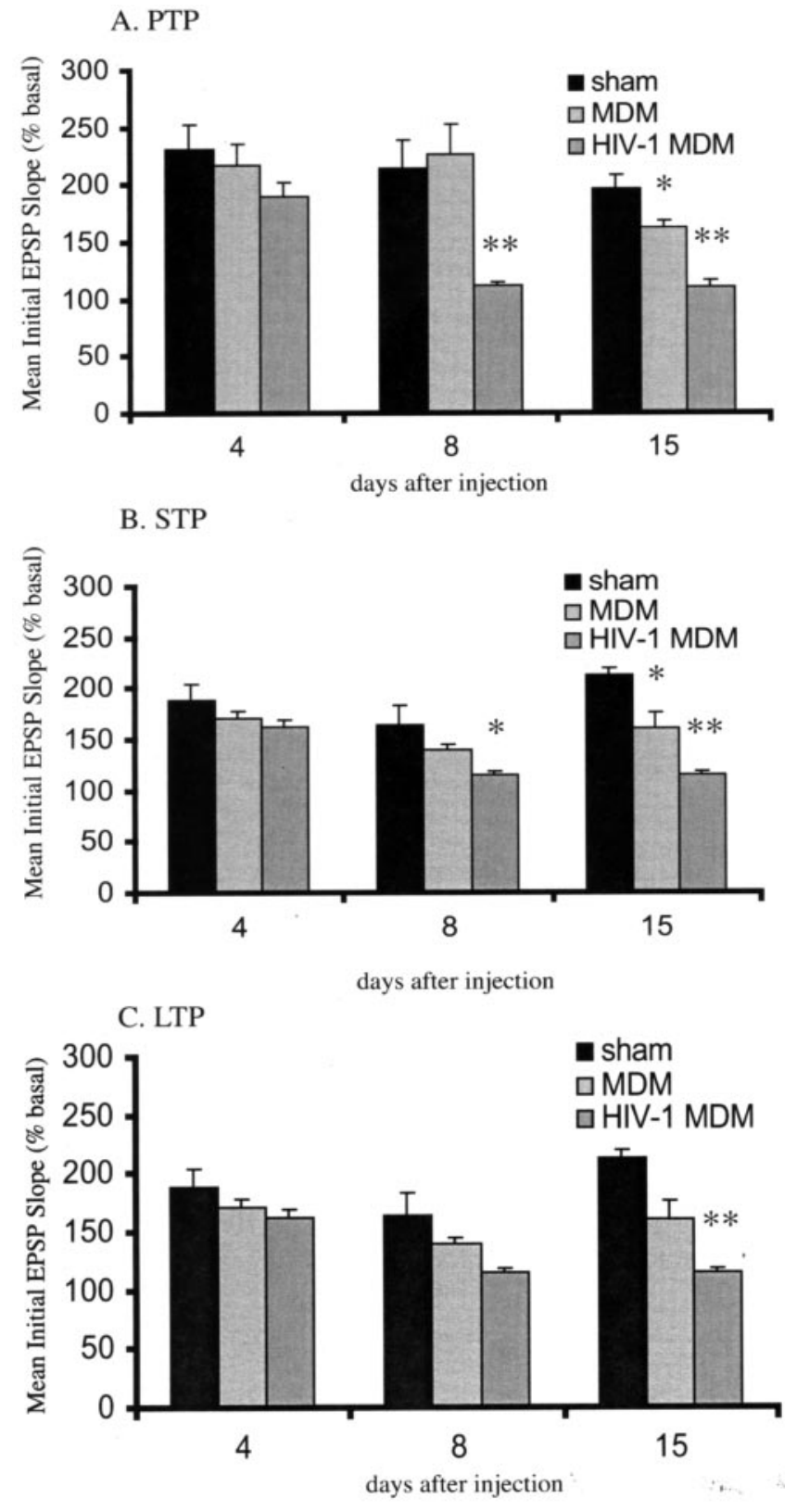

Figure 5. HFS-dependent PTP, STP, and LTP. The bar graphs depict average percentage change in field EPSP slope compared with basal (pretetanic) in the hippocampal CA1 subfield. Basal values for each group were gathered 15-5 min before high-frequency stimulation $(t=15-25$ in Fig. 1). PTP, STP, and LTP were measured at $t=31-35,40-45$, and 85-90 (Fig. 4). Statistical comparisons were made against shams $\left({ }^{*} p<\right.$ $0.01,{ }^{* *} p<0.001$; ANOVA, Tukey-Kramer).

nistic studies of dementia in HIV-1-infected humans. Additionally, subtoxic changes in neuronal antigen distribution resemble processes occurring in the human hippocampus in HAD. Postmortem evaluation of humans with HIVE showed a 50-90\% decrease in density of parvalbumin-positive hippocampal neurons in the CA3 subregion (Masliah et al., 1992a). The reduction of parvalbumin expression in CA3 correlated strongly with progression to HAD, whereas neocortical changes in parvalbumin density failed to correlate with dementia. Despite alterations in immunoreactivity, the absolute number of hippocampal neurons in human HIVE remains unchanged compared with healthy 


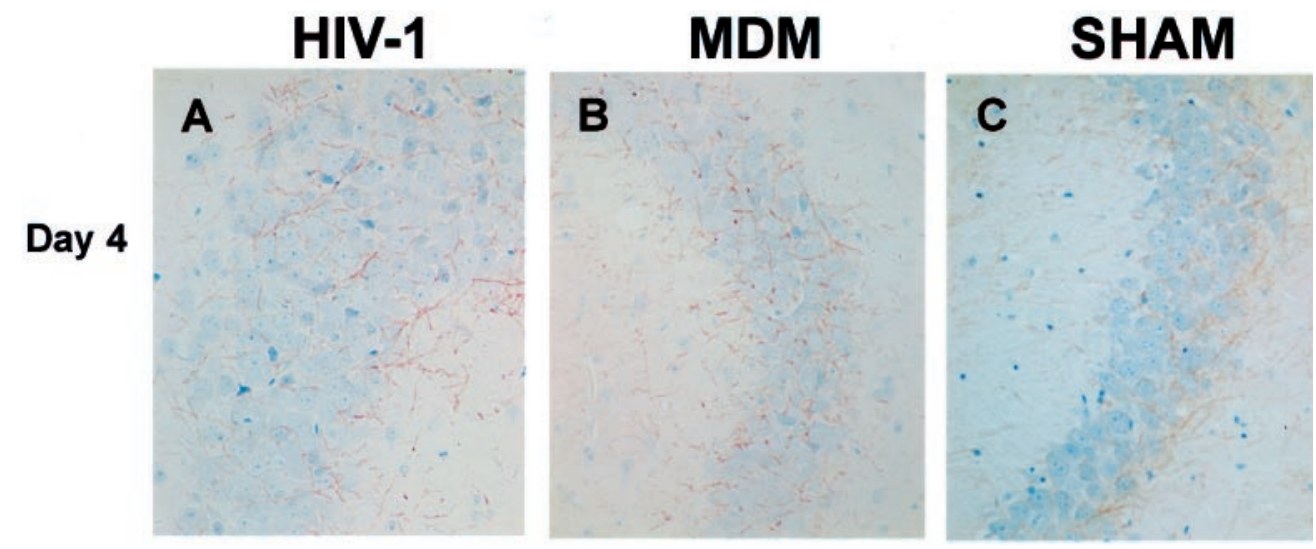

Figure 6. Distribution of NF antigen within the hippocampal CA2 subregion. Three treatment groups $(H I V-1, M D M$, and $S H A M)$ at three time points $(4,8$, and $15 \mathrm{~d}$ after injection) are shown $(200 \times)$. All sections shown are ipsilateral to the injection. Diaminobenzidine was used as a peroxidase substrate, and all sections were counterstained with Mayer's hematoxylin.
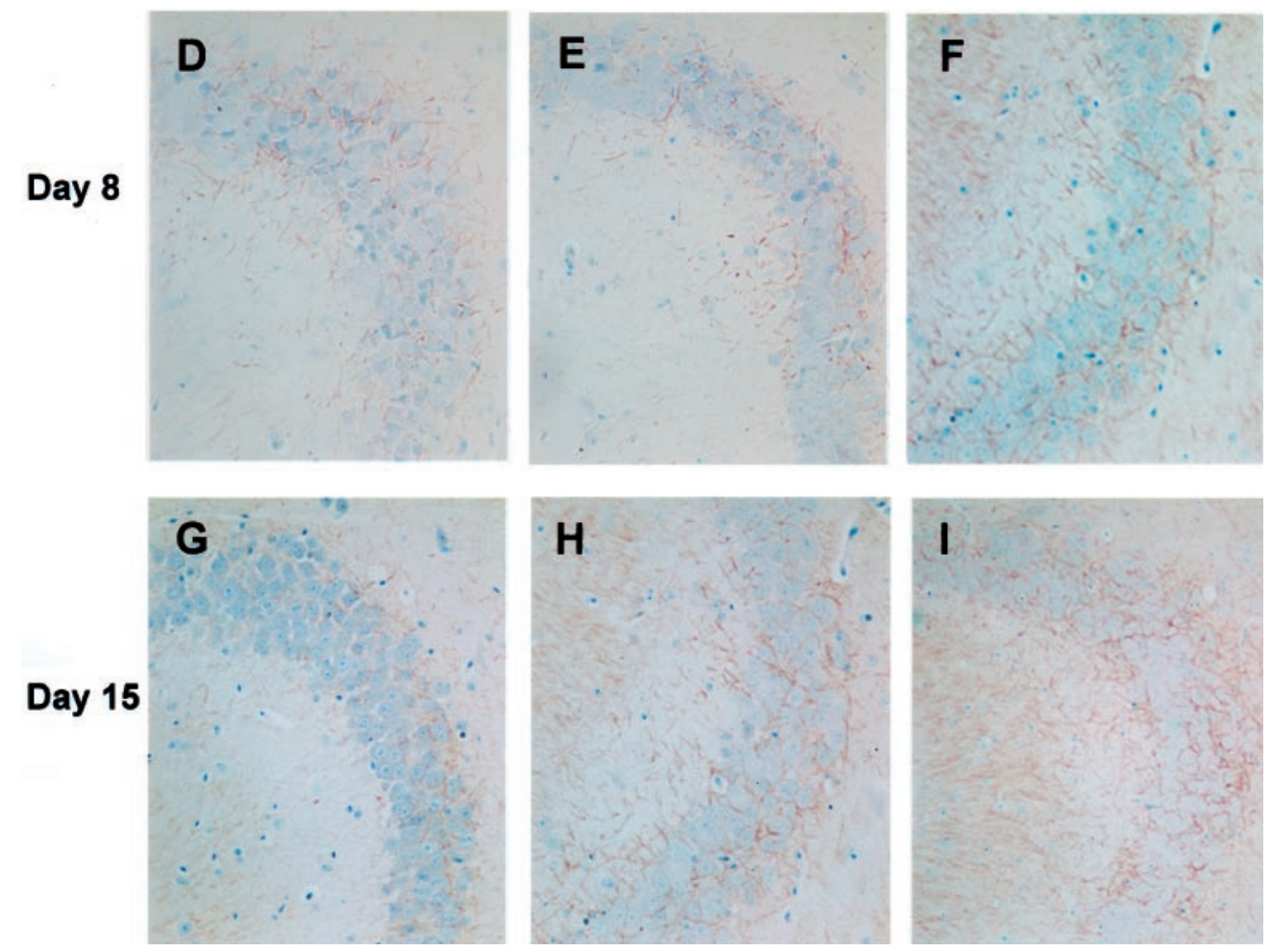

individuals (Korbo and West, 2000), suggesting that hippocampal changes in HAD are not associated with frank neuronal dropout. From a therapeutic perspective, the responsiveness of HAD to HAART therapy (Gendelman et al., 1998) supports the idea that neuronal damage in HIV-1 disease is a reversible process. The experimental finding that cognitive deficits in HIVE mice are transient further likens xenograft-induced murine HIVE to the natural form of the disease in humans.

Second, we have shown that immune-activated macrophages, although detected frequently in the HIVE brain, need not exist in a specific brain region to cause physiologic impairment. MDM release of proinflammatory factors such as interleukin (IL)-1, IL-6, and tumor necrosis factor (TNF- $\alpha$ ) is a likely inciting event and remains a potential therapeutic target. However, the mechanism for propagation of proinflammatory signals from basal ganglia to hippocampus remains unidentified. It is possible that diffusible factors traveling through brain parenchyma and/or cerebrospinal fluid may influence neuronal homeostasis and function (Persidsky et al., 1999). Diffusible toxins may follow various paths of least resistance through brain parenchyma, such as the perivas- cular compartment or axonal projections traveling to or away from the basal ganglia. Future studies investigating the rate and route of labeled protein diffusion through the HIVE SCID mouse brain are necessary to test the plausibility of this hypothesis. Alternatively, protein diffusion may not be as important as paracrine mechanisms of glial activation. MDM-derived proinflammatory cytokines are potent activators of both astrocytes and microglia (Lee et al., 1993; Chiang et al., 1994; Van Wagoner et al., 1999; Woiciechowsky et al., 1999; Cardinaux et al., 2000; Schubert et al., 2000), and a central inflammatory focus may propagate glial activation throughout the brain. In another but not mutually exclusive pathogenic model, local secretion of proinflammatory cytokines into microvasculature may activate microvascular endothelial cells throughout the brain, leading to progressive blood-brain barrier compromise (Persidsky et al., 1999), influx of viral and immune factors from the periphery, and ultimately, altered neuronal function and morphology. Still another possibility is that hippocampal efferent projection neurons terminating in or traveling through basal ganglia may sustain damage resulting in Wallerian degeneration. Along this line of thought, afferent projections to hippocampus traveling 

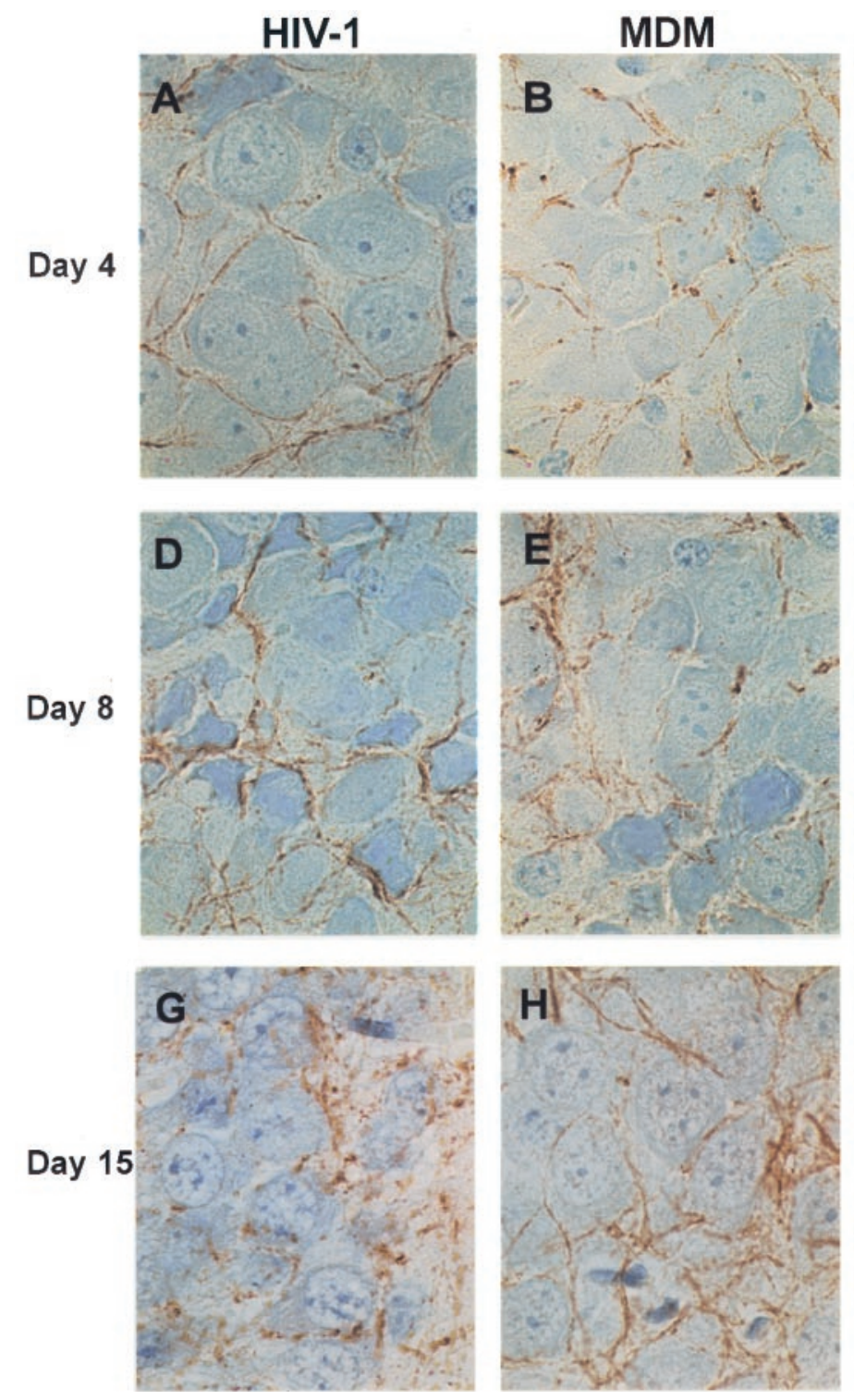
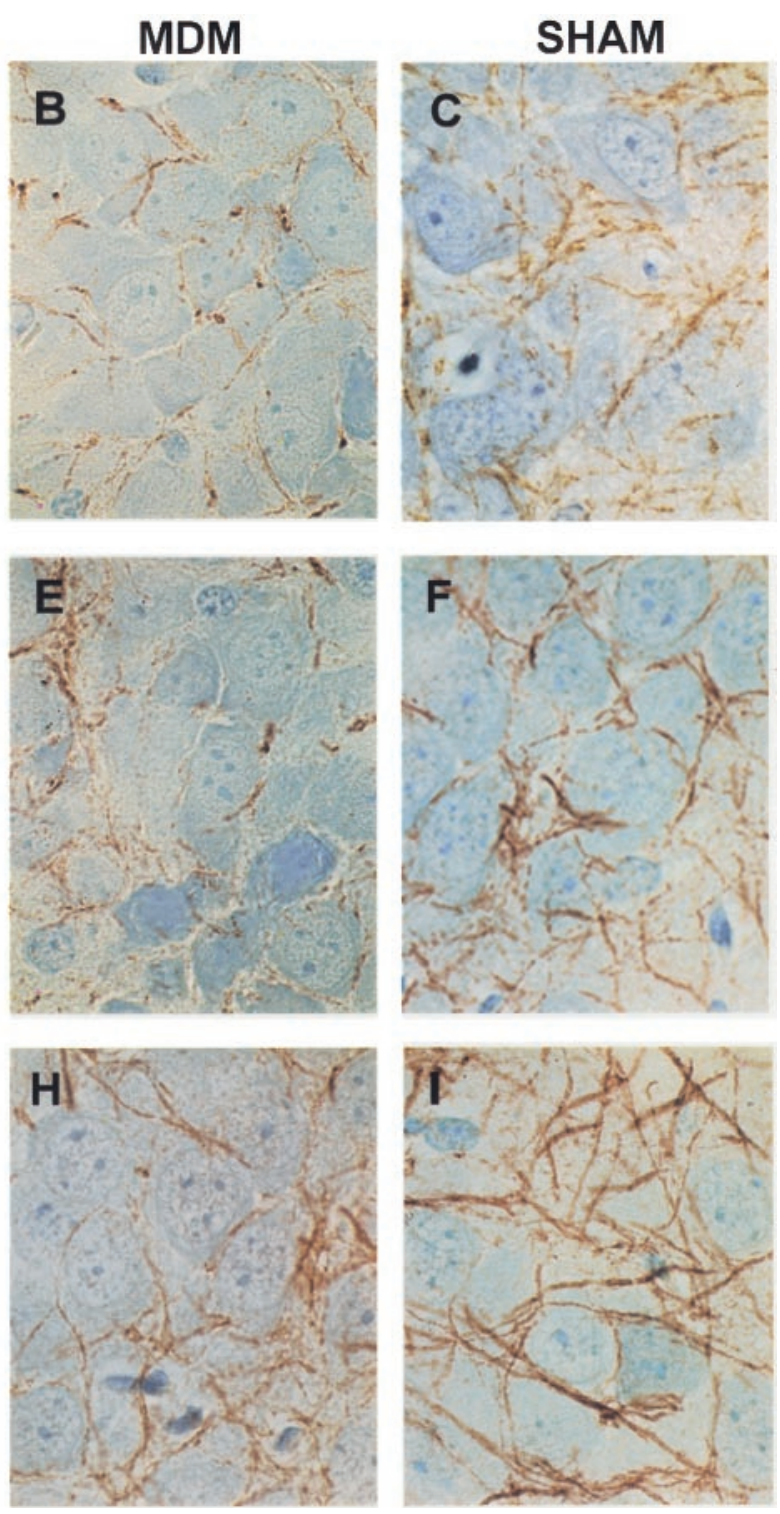

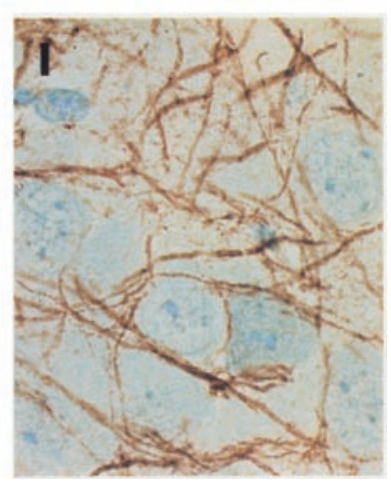

Figure 7. Distribution of NF antigen in the CA2 hippocampal subregion. All panels show the same hippocampal sections as Figure 6. The region of highest NF density within CA2 was chosen for this montage and quantification $(1000 \times)$. through basal ganglia may sustain damage resulting in decreased input to hippocampal subregions. For example, both thalamicocortical and corticofugal neurons can pass through the lateral and medial ganglionic eminences en route to and from the hippocampus. Although we cannot discount the role of projection neuron destruction in the HIVE SCID mouse model, inflammationmediated damage to projection neurons appears unlikely to be involved in human HAD on the basis of radiologic (Chrysikopoulos et al., 1990; Aylward et al., 1993, 1995; Jernigan et al., 1993; Marcus et al., 1998) and postmortem histopathologic evidence showing that HIVE is a diffuse process preferentially affecting subcortical white matter and deep brain structures but lacking discrete foci of injury (Gray et al., 1988; Masliah et al., 1992a,b, 2000).

Third, the major antecedent to impaired synaptic physiology and morphology appears to be the presence of MDMs in brain. Viral infection of injected MDMs augments the magnitude of hippocampal pathophysiology, probably by increasing the levels of secreted proinflammatory cytokines, but is not necessary for development of disease. The ability of brain MDMs to cause dementia indepen- dent of viral infection supports the idea that activated macrophages trigger final common pathways of neurodegeneration. In humans, the presence of activated macrophages and microglia in the brain is a better predictor of neurologic decline than detection of viral proteins or nucleic acids (Glass et al., 1993; Persidsky et al., 1999). This is not the first report of cognitive impairment and neuropathology associated with retrovirus-infected leukocytes in the murine brain. Mice inoculated intraperitoneally with the LP-BM5 murine retrovirus mixture displayed deficient MWM performance 5-7 weeks after inoculation (Sei et al., 1992), before the appearance of astrogliosis and microglial activation (Kustova et al., 1996) and reduced expression of neuronal cytoskeletal proteins in the frontal and parietal lobes (Kustova et al., 1998). Unlike the SCID mouse model of HIVE, LP-BM5 neuropathology is not associated with the presence of immune-competent, retrovirus-infected mononuclear phagocytes (monocytes, macrophages, and microglia) in brain parenchyma. Still, LP-BM5-associated neuronal damage is suppressed in TNF- $\alpha^{-1-}$ animals (Iida et al., 2000) and in wild-type animals treated with a glutamate antagonist (Kustova et al., 1998). The requirement of TNF- $\alpha$ production for development 


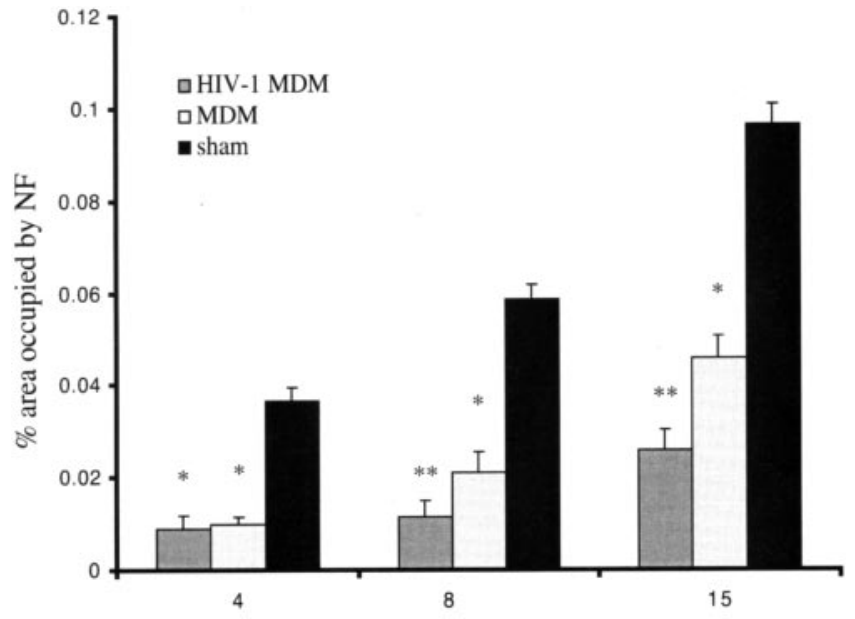

Days After Injection

Figure 8. Neurofilament (NF) expression within the CA2 hippocampal subfield ipsilateral to injection. After slides were analyzed on low power $(20 \times)$, the region of highest NF intensity was selected, photographed at $100 \times$ magnification, and quantified using ImageQuant software. Statistical comparisons were made against shams $\left({ }^{*} p<0.05,{ }^{*} p<0.01\right.$; ANOVA, Tukey-Kramer).

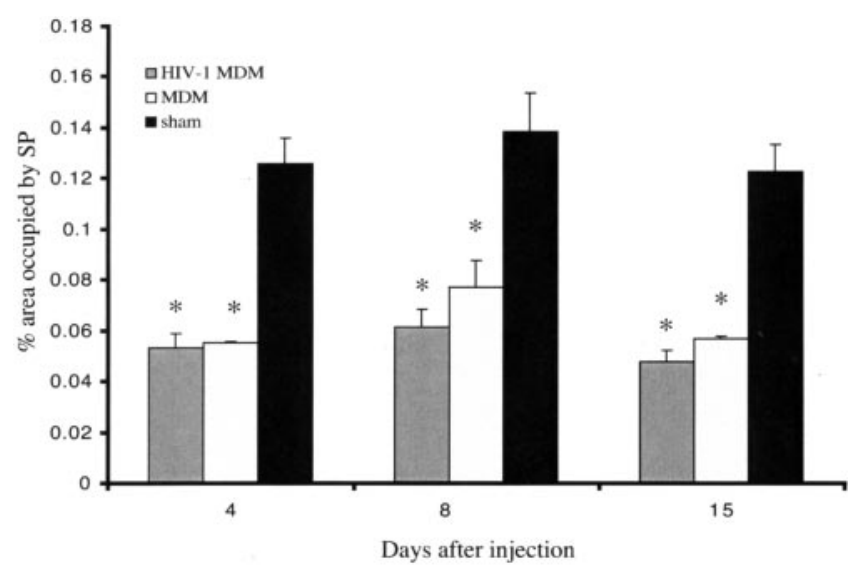

Figure 9. Synaptophysin (SP) expression within the CA2 hippocampal subfield ipsilateral to injection. Visual fields $(100 \times)$ within CA2 were chosen for quantification as described in Figure 8. Statistical comparisons were made against shams $\left({ }^{*} p<0.05\right.$; ANOVA, Tukey-Kramer).

of LP-BM5 neuropathology suggests that activation and immune competence of monocytes and macrophages may be the crucial inflammatory event preceding neurodegeneration in retrovirusmediated encephalopathy. The participation of glutamate in LPBM5-mediated toxicity alludes to excitatory neurotoxicity as a final pathway for neuronal degeneration (Jiang et al., 2001).

The development of vaccines, anti-retroviral, and adjunctive therapeutics aimed at treating the neurologic aspects of HIV-1 infection necessitates relevant animal model systems. Because this model system parallels human disease, it likely will continue to provide useful information in studies of HIV-1 neuropathogenesis.

\section{REFERENCES}

Aylward EH, Henderer JD, McArthur JC, Brettschneider PD, Harris GJ, Barta PE, Pearlson GD (1993) Reduced basal ganglia volume in HIV1 -associated dementia: results from quantitative neuroimaging. Neurology 43:2099-2104.

Aylward EH, Brettschneider PD, McArthur JC, Harris GJ, Schlaepfer TE, Henderer JD, Barta PE, Tien AY, Pearlson GD (1995) Magnetic resonance imaging measurement of gray matter volume reductions in HIV dementia. Am J Psychol 152:987-994.

Bliss TVP, Collingridge GL (1993) A synaptic model of memory: longterm potentiation in the hippocampus. Nature 361:31-39.

Cardinaux JR, Allaman I, Magistretti PJ (2000) Pro-inflammatory cytokines induce the transcription factors C/EBPbeta and C/EBPdelta in astrocytes. Glia 29:91-97.

Chakrabarti L, Hurtrel M, Maire MA, Vazeux R, Dormont D, Montagnier L, Hurtrel B (1991) Early viral replication in the brain of SIVinfected rhesus monkeys. Am J Pathol 139:1273-1280.

Chapman PF, White GL, Jones MW, Cooper-Blacketer D, Marshall VJ, Irizarry M, Younkin L, Good MA, Bliss TV, Hyman BT, Younkin SG, Hsiao KK (1999) Impaired synaptic plasticity and learning in aged amyloid precursor protein transgenic mice. Nat Neurosci 2:271-276.

Chiang CS, Stalder A, Samimi A, Campbell IL (1994) Reactive gliosis as a consequence of interleukin-6 expression in the brain: studies in transgenic mice. Dev Neurosci 16:212-221.

Chou SM, Wang HS, Taniguchi A, Bucala R (1998) Advanced glycation end products in neurofilament conglomeration of motoneurons in familial and sporadic amyotrophic lateral sclerosis. Mol Med 4:324-332.

Chrysikopoulos HS, Press GA, Grafe MR, Hesselink JR, Wiley CA (1990) Encephalitis caused by human immunodeficiency virus: CT and MR imaging manifestations with clinical and pathologic correlation. Radiology 175:185-191.

Clements JE, Zink MC, Narayan O, Gabuzda DH (1994) Lentivirus infection of macrophages. Immunol Ser 60:589-600.

Cunningham MG, McKay RD (1993) A hypothermic miniaturized stereotaxic instrument for surgery in newborn rats. J Neurosci Methods 47:105-114.

Dore GJ, Correll PK, Li Y, Kaldor JM, Cooper DA, Brew BJ (1999) Changes to AIDS dementia complex in the era of highly active antiretroviral therapy. AIDS 13:1249-1253.

Gendelman HE, Narayan O, Molineaux S, Clements JE, Ghotbi Z (1985) Slow, persistent replication of lentiviruses: role of tissue macrophages and macrophage precursors in bone marrow. Proc Natl Acad Sci USA 82:7086-7090.

Gendelman HE, Orenstein JM, Martin MA, Ferrua C, Mitra R, Phipps T, Wahl LA, Lane HC, Fauci AS, Burke DS (1988) Efficient isolation and propagation of human immunodeficiency virus on recombinant colony-stimulating factor 1-treated monocytes. J Exp Med 167:1428-1441.

Gendelman HE, Zheng J, Coulter CL, Ghorpade A, Che M, Thylin M, Rubocki R, Persidsky Y, Hahn F, Reinhard Jr J, Swindells S (1998) Suppression of inflammatory neurotoxins by highly active antiretroviral therapy in human immunodeficiency virus-associated dementia. J Infect Dis 178:1000-1007.

Glass JD, Wesselingh SL, Selnes OA, McArthur JC (1993) Clinical neuropathologic correlation in HIV-associated dementia. Neurology 43:2230-2237.

Gray F, Gherardi R, Scaravilli F (1988) The neuropathology of the acquired immune deficiency syndrome (AIDS). A review. Brain 111:245-266.

Heijink E, Scholten SW, Bolhuis PA, de Wolff FA (2000) Effects of 2,5-hexanedione on calpain-mediated degradation of human neurofilaments in vitro. Chem Biol Interact 129:231-247.

Ho N, Liauw JA, Blaeser F, Wei F, Hanissian S, Muglia LM, Wozniak DF, Nardi A, Arvin KL, Holtzman DM, Linden DJ, Z huo M, Muglia LJ, Chatila TA (2000) Impaired synaptic plasticity and cAMP response element-binding protein activation in $\mathrm{Ca}^{2+} /$ calmodulindependent protein kinase type IV/Gr-deficient mice. J Neurosci 20:6459-6472.

Hurtrel B, Chakrabarti L, Hurtrel M, Montagnier L (1993) Target cells during early SIV encephalopathy. Res Virol 144:41-46.

Iida R, Saito K, Yamada K, Basile AS, Sekikawa K, Takemura M, Fujii H, Wada H, Seishima M, Nabeshima T (2000) Suppression of neurocognitive damage in LP-BM5-infected mice with a targeted deletion of the TNF-alpha gene. FASEB J 14:1023-1031.

Janssen R, Cornblath D, Epstein L, Foa R, McArthur J, Price R, Asbury A, Beckett A, Benson D, Bridge T, Levanthal C, Satz P, Saykin A, Sidtis J, Tross S (1991) Nomenclature and research case definitions for neurological manifestations of human immunodeficiency virus type 1 (HIV-1) infection. Neurology 41:778-785.

Jernigan TL, Archibald S, Hesselink JR, Atkinson JH, Velin RA, McCutchan JA, Chandler J, Grant I (1993) Magnetic resonance imaging morphometric analysis of cerebral volume loss in human immunodeficiency virus infection. The HNRC Group. Arch Neurol 50:250-255.

Jiang ZG, Piggee C, Heyes MP, Murphy C, Quearry B, Bauer M, Zheng J, Gendelman HE, Markey SP (2001) Glutamate is a mediator of neurotoxicity in secretions of activated HIV-1-infected macrophages. J Neuroimmunol 117:97-107.

Kalter DC, Nakamura JA, Turpin JA, Baca LM, Hoover DL, Dieffenbach C, Ralph P, Gendelman HE, Meltzer MS (1991) Enhanced HIV replication in macrophage colony-stimulating factor-treated monocytes. J Immunol 146:298-306. 
Korbo L, West M (2000) No loss of hippocampal neurons in AIDS patients. Acta Neuropathol (Berl) 99:529-533.

Kubota M, Murakoshi T, Saegusa H, Kazuno A, Zong S, Hu Q, Noda T, Tanabe T (2001) Intact LTP, fear memory but impaired spatial memory in mice lacking $\mathrm{Ca}(\mathrm{v}) 2.3$ (alpha(IE)) channel. Biochem Biophys Res Commun 282:242-248.

Kustova Y, Sei Y, Goping G, Basile AS (1996) Gliosis in the LP-BM5 murine leukemia virus-infected mouse: an animal model of retrovirusinduced dementia. Brain Res 742:271-282.

Kustova Y, Espey MG, Sung EG, Morse D, Sei Y, Basile AS (1998) Evidence of neuronal degeneration in C57B1/6 mice infected with the LP-BM5 leukemia retrovirus mixture. Mol Chem Neuropathol 35:39-59.

Lee SC, Liu W, Dickson DW, Brosnan CF, Berman JW (1993) Cytokine production by human fetal microglia and astrocytes. Differential induction by lipopolysaccharide and IL-1 beta. J Immunol 150:2659-2667.

Lu YM, Jia Z, Janus C, Henderson JT, Gerlai R, Wojtowicz JM, Roder JC (1997) Mice lacking metabotropic glutamate receptor 5 show impaired learning and reduced CA1 long-term potentiation (LTP) but normal CA3 LTP. J Neurosci 17:5196-5205.

Marcus CD, Taylor-Robinson SD, Sargentoni J, Ainsworth JG, Frize G, Easterbrook PJ, Shaunak S, Bryant DJ (1998) 1H MR spectroscopy of the brain in HIV-1-seropositive subjects: evidence for diffuse metabolic abnormalities. Metab Brain Dis 13:123-136.

Maschke M, Kastrup O, Esser S, Ross B, Hengge U, Hufnagel A (2000) Incidence and prevalence of neurological disorders associated with HIV since the introduction of highly active antiretroviral therapy (HAART). J Neurol Neurosurg Psychiatry 69:376-380.

Masliah E, Ge N, Achim CL, Hansen LA, Wiley CA (1992a) Selective neuronal vulnerability in HIV encephalitis. J Neuropathol Exp Neurol 51:585-593.

Masliah E, Morey GM, Teresa RD, Terry RD, Wiley CA (1992b) Cortical dendritic pathology in human immunodeficiency virus encephalitis. Lab Invest 66:285-291.

Masliah E, DeTeresa RM, Mallory ME, Hansen LA (2000) Changes in pathological findings at autopsy in AIDS cases for the last 15 years. AIDS 14:69-74.

McHugh TJ, Blum KI, Tsien JZ, Tonegawa S, Wilson MA (1996) Impaired hippocampal representation of space in CA1-specific NMDAR1 knockout mice. Cell 87:1339-1349.

Michaels J, Sharer LR, Epstein LG (1988) Human immunodeficiency virus type 1 (HIV-1) infection of the nervous system: a review. Immunodefic Rev 1:71-104.

Molinari S, Battini R, Ferrari S, Pozzi L, Killcross AS, Robbins TW, Jouvenceau A, Billard JM, Dutar P, Lamour Y, Baker WA, Cox H, Emson PC (1996) Deficits in memory and hippocampal long-term potentiation in mice with reduced calbindin D28K expression. Proc Natl Acad Sci USA 93:8028-8033.

Montine TJ, Farris DB, Graham DG (1995) Covalent crosslinking of neurofilament proteins by oxidized catechols as a potential mechanism of Lewy body formation. J Neuropathol Exp Neurol 54:311-319.

Morris R (1984) Developments of a water-maze procedure for studying spatial learning in the rat. J Neurosci Methods 11:47-60.

Murphy KP, Carter RJ, Lione LA, Mangiarini L, Mahal A, Bates GP, Dunnett SB, Morton AJ (2000) Abnormal synaptic plasticity and impaired spatial cognition in mice transgenic for exon 1 of the human Huntington's disease mutation. J Neurosci 20:5115-5123.

Nalbantoglu J, Tirado-Santiago G, Lahsaini A, Poirier J, Goncalves O, Verge G, Momoli F, Welner SA, Massicotte G, Julien JP, Shapiro ML (1997) Impaired learning and LTP in mice expressing the carboxy terminus of the Alzheimer amyloid precursor protein. Nature 387:500-505.

Narayan O, Clements JE (1989) Biology and pathogenesis of lentiviruses. J Gen Virol 70:1617-1639.
Narayan O, Joag SV, Stephens EB (1995) Selected models of HIVinduced neurological disease. Curr Top Microbiol Immunol 202:151-166.

Persidsky Y, Gendelman HE (1997) Development of laboratory and animal model systems for HIV-1 encephalitis and its associated dementia. J Leukoc Biol 62:100-106.

Persidsky Y, Nottet HS, Sasseville VG, Epstein LG, Gendelman HE (1995) The development of animal model systems for HIV-1 encephalitis and its associated dementia. J Neurovirol 1:229-243.

Persidsky Y, Limoges J, McComb R, Bock P, Baldwin T, Tyor W, Patil A, Nottet HSLM, Epstein L, Gelbard H, Flanagan E, Reinhard J, Pirruccello SJ, Gendelman HE (1996) Human immunodeficiency virus encephalitis in SCID mice. Am J Pathol 149:1027-1053.

Persidsky Y, Buttini M, Limoges J, Bock P, Gendelman HE (1997) An analysis of HIV-1-associated inflammatory products in brain tissue of humans and SCID mice with HIV-1 encephalitis. J Neurovirol 3:401-416.

Persidsky Y, Ghorpade A, Rasmussen J, Limoges J, Liu XJ, Stins M, Fiala M, Way D, Kim KS, Witte MH, Weinand M, Carhart L, Gendelman HE (1999) Microglial and astrocyte chemokines regulate monocyte migration through the blood-brain barrier in human immunodeficiency virus-1 encephalitis. Am J Pathol 155:1599-1611.

Petitto JM, McNamara RK, Gendreau PL, Huang Z, Jackson AJ (1999) Impaired learning and memory and altered hippocampal neurodevelopment resulting from interleukin-2 gene deletion. J Neurosci Res 56:441-446.

Price RW, Brew BJ, Sidtis J, Rosenblum M, Scheck AC, Cleary P (1988) The brain in AIDS: central nervous system HIV-1 infection and AIDS dementia complex. Science 239:586-592.

Rosenstein JM, Silverman WF (2000) Protein synthesis inhibition in neocortical grafts evaluated by systemic amino acid uptake autoradiography. Exp Neurol 162:268-277.

Schubert P, Morino T, Miyazaki H, Ogata T, Nakamura Y, Marchini C, Ferroni S (2000) Cascading glia reactions: a common pathomechanism and its differentiated control by cyclic nucleotide signaling. Ann NY Acad Sci 903:24-33.

Sei Y, Arora PK, Skolnick P, Paul IA (1992) Spatial learning impairment in a murine model of AIDS. FASEB J 6:3008-3013.

Sills RC, Valentine WM, Moser V, Graham DG, Morgan DL (2000) Characterization of carbon disulfide neurotoxicity in C57BL6 mice: behavioral, morphologic, and molecular effects. Toxicol Pathol 28:142-148.

Stiles J (2000) Neural plasticity and cognitive development. Dev Neuropsychol 18:237-272.

Uetani N, Kato K, Ogura H, Mizuno K, Kawano K, Mikoshiba K, Yakura H, Asano M, Iwakura Y (2000) Impaired learning with enhanced hippocampal long-term potentiation in PTPdelta-deficient mice. EMBO J 19:2775-2785.

Van der Zee EA, Naber PA, Disterhoft JF (1997) Age-dependent changes in the immunoreactivity for neurofilaments in rabbit hippocampus. Neuroscience 79:103-116.

Van Wagoner NJ, Oh JW, Repovic P, Benveniste EN (1999) Interleukin-6 (IL-6) production by astrocytes: autocrine regulation by IL-6 and the soluble IL-6 receptor. J Neurosci 19:5236-5244.

Woiciechowsky C, Schoning B, Daberkow N, Asche K, Stoltenburg G, Lanksch WR, Volk HD (1999) Brain-IL-1beta induces local inflammation but systemic anti-inflammatory response through stimulation of both hypothalamic-pituitary-adrenal axis and sympathetic nervous system. Brain Res 816:563-571.

Xiong H, Baskys A, Wojtowicz JM (1996) Brain-derived peptides inhibit synaptic transmission via GABAB receptors in CA1 area of rats. Brain Res 737:188-194. 